\title{
The Effect of Internalization of Local Wisdom Si Tou Timou Tumou Tou through Civic Education Learning on Increasing Students 'Tolerance Attitudes
}

\author{
Arie Supriati, Theodorus Pangalila, Apeles Lexi Lonto, Julien Biringan
}

\begin{abstract}
This study aims to examine the effect of the internalization of Si Tou Timou Tumou's cultural values in Civic Education learning on increasing students' tolerance attitudes. This research was conducted in Tomohon City, North Sulawesi Province, towards high school students in class XI. The main problem of this research is how the influence of $\mathrm{Si}$ Tou Timou Tumou Tou's internalization of cultural values in Civic Education learning to increase students' tolerance attitudes. The supporting theory of this research is the theory of internalization, culture, cultural values (local wisdom / local wisdom), Civic Education learning and the theory of tolerance. To answer the research problem, the data used are data in the form of numbers obtained from the results of the questionnaire with measurements using a Likert scale for the variables Si Tou Timou Tumou Tou and student tolerance attitudes, while the Civic Education learning variable uses the SSHA scale (Survey of Study Habits and Attitudes). Besides that, the supporting data was obtained through interviews and documentation studies. The sampling technique used in this study was cluster sampling with the primary data source being students of class XI (120 students) from five sample schools. For processing and data analysis, the approach used in this study is a quantitative approach by testing hypotheses using path analysis (path analysis) to see the relationship between the variables under study. The results of the analysis of the research data show that: First, the cultural value of Si Tou Timou Tumou Tou does not have a positive effect on Civic Education learning because in this context cultural values are only a small part of Civic Education learning content in high schools in Tomohon city of North Sulawesi. Second, Civic Education Learning has a significant influence on the development of Student Tolerance Attitudes. Where Civic Education learning is well prepared and cultural values that want to be internalized are well identified, well taught and well evaluated, the better the student tolerance attitude is. Third, the cultural value of Si Tou Timou Tumou Tou and Civic Education Learning together have a positive influence and significantly influence the development of student tolerance attitudes. Based on the findings of the study, this study recommends further research in the form of the development of Civic Education learning models based on local cultural values.
\end{abstract}

Index Terms: Internalization, Local Wisdom, Si Tou Timou Tumou Tou, Civic Education, Tolerance Attitude

Revised Manuscript Received on September 22, 2019 Arie Supriati, Universitas Negeri Manado

Theodorus Pangalila, Universitas Negeri Manado,

theopangalila@unima.ac.id

Apeles Lexi Lonto, Universitas Negeri Manado

Julien Biringan, Universitas Negeri Manado

\section{INTRODUCTION}

Indonesia regarding many aspects is a pluralistic nation. This pluralism is evident in the manifestation of Indonesian culture that is not "one." Indonesian social and cultural pluralism is characterized by a large number of cultures and religions in Indonesia. For example, Javanese, Sundanese, Minahasa, Batak, and others. Regarding religion in Indonesia, there are six religions that are officially recognized by the government: Islam, Protestantism, Catholicism, Hinduism, Buddhism and Confucianism (Pangalila, Ngarawula, \& Sadhana, 2018).

Inevitably, Indonesia is indeed a nation consisting of various cultures and customs. Unfortunately, the implementation of the process of community life in the midst of these differences and diversity (ethnicity, culture, race, religion, and the like) is not as easy as what is thought. The shift between different religious groups and ethnic groups, cultures or customs seems to be the trigger for a horizontal divide between these different societies. Since 1997 our country has been hit by various kinds of conflicts. Conflicts occur in various regions in Indonesia, for example in Ambon, Papua, Kalimantan, Posso, and in other regions in Indonesia. Conflict between groups in society seems inevitable in various regions of our country. In Ambon, for example, the initial conflict only occurred between a group of people and eventually developed into an interfaith conflict and spread to surrounding areas. The conflicts that occurred in various regions resulted in many casualties and even material victims. With this conflict many people were killed and killed each other; many people lost their homes because of the destruction of the masses, some of them fled to other islands. These conflicts are indeed ironic for the Indonesian state which adheres to the concept of Unity in Diversity. Exactly what Syaqiq A. Mughni said was that although formally this nation recognized diversity, in reality, it was not (Mahfud, 2009).

The phenomena of conflict that occur in Indonesia today indicate a lack of tolerance; good tolerance towards other religions and other cultures. Tolerance, in essence, is an attitude and action that respects differences in religion, ethnicity, ethnicity, opinions, attitudes, and 
actions of other people that are different from him (Kementerian Pendidikan dan Kebudayaan RI, 2010; Pangalila, 2013).

In contrast to what happened in various regions in Indonesia which were hit by various horizontal conflicts, the harmony of the people of North Sulawesi was maintained well; the community remains calm, safe, and peaceful in harmony. North Sulawesi seems without problems, even though the residents of this province are also diverse in ethnicity, religion, race, and language.

Because of the harmony is shown by the people of North Sulawesi in the midst of a diversity of tribes, religions, races, and languages, it is not surprising that North Sulawesi is a barometer regarding harmony and dialogue between religious groups in Indonesia. Many regional leaders specifically came to North Sulawesi to learn firsthand about the inter-religious harmony. According to Gara in Pangalila (2013), religious harmony in North Sulawesi is a reality. This is recognized at the local, national and even international levels. The fact is that when other areas around North Sulawesi (SULUT) were emotionally burned to the conflict in the name of religion (ethnicity), it turned out that SULUT was difficult to ignite and live in harmony (Pangalila, 2013).

The phenomenon of harmony displayed by the people of North Sulawesi raises fundamental questions: what are the factors that cause North Sulawesi, which regarding ethnicity, ethnicity, religion, and diverse languages can live in harmonious situations? What socio-cultural values exist in the SULUT community that become glue so that it is difficult to provoke?

The initial conclusion obtained why North Sulawesi people live in harmony is the strong dominant local wisdom of Si Tou Timou Tumou Tou animating people's lives. Si Tou Timou Tumou Tou (a human being to humanize other people) is Sam Ratulangi's philosophy. This philosophical thought inspired the life of the Minahasa people and even the entire North Sulawesi community to live in harmony with the aim of humanizing others and not being enemies of others (homo homini lupus).

An important factor that also influences the strong cultural values of North Sulawesi is inheriting cultural values for generations or better known as the enculturation process. Koentjaraningrat (2002) states that "in the enculturation process an individual learns and adapts his mind and attitude to customs, systems of norms, and rules that live in his culture." Then the enculturation process is carried out by parents or people who considered to be in the community, such as inheritance of the values of manners, customs, skills of a tribe/family that are passed on to the next generation. The enculturation process usually takes place formally through education to be conveyed to others who are not familiar, the delivery of information as well as a form of awareness of the existence of a culture and then adopting that culture to serve as its culture. In Indonesia education oriented to the internalization of socio-cultural values of society implicitly has been mandated in the implementation of legislation in force in Indonesia. In the Constitution of the
Republic of Indonesia Number 20 of 2003 concerning the National Education System it is stated that "education is held democratically by upholding human rights, religious values, cultural values, and national plurality", further stated that "education is held as a process of civilization and the empowerment of students that lasts for life" (Pangalila, 2013).

In the Constitution No. 20 of 2003 concerning the National Education System (Sisdiknas) article 37, Civics Education is placed as the name of compulsory subjects for primary and secondary education curricula and compulsory subjects for higher education curricula. In the explanation section, this is emphasized again that "Civics education is intended to form students to be human beings who have a sense of nationality and love for the country." Civics Education is the right tool to internalize the socio-cultural values of the community.

The goal to be achieved through the internalization of North Sulawesi's cultural values in the context of Civics Education Learning here is to develop the Attitude of Student Tolerance so that they can respond to diversity positively. In connection with efforts to increase the attitude of Tolerance of Students, Raihani (2011) argues: Education is seen as the most effective means, in the long term, to enable tolerance to flourish amongst people in a diverse society. School as an educational institution plays a pivotal role in promoting tolerance. It is where children learn and internalize values relevant to their life. Governments, educationists, and researchers have made some tremendous efforts to ensure that a school is a place of effective tolerance education.

Education is seen as the most effective way, in the long term, that allows the development of tolerance between people in diverse societies. Schools as an educational institution play an essential role in promoting tolerance. Schools are places where children learn and internalize important values for their lives. Governments, educators, and researchers have made some extraordinary efforts to ensure that schools are a productive place for tolerance education (Pangalila, 2013).

The results of preliminary observations indicate that the attitude of tolerance of high school students in North Sulawesi and especially the city of Tomohon is well-maintained. This is evidenced by the mutual understanding between students who come from different cultural, ethnic, religious and linguistic backgrounds. Until now there has never been an event that shows a conflict between students caused by differences in student backgrounds. Based on the background above, the identified research problems are: How Does the Effect of Internalization of Local Wisdom Si Tou Timou Tumou Tou in Civics Education Learning Against the Development of Student Tolerance Attitudes? 


\section{LITERATURE REVIEW}

\section{A. Definition of Internalization}

Epistemologically the word internalization comes from internal words or internal words which mean the inside or inside. Whereas internalization shows a process. In the Indonesian language rule, the suffix suffix is defined as a process. So simple internalization can be interpreted as "a process of inserting it in." In the Great Dictionary of Indonesian Language internalization is the appreciation of a doctrine, doctrine, or value so that it is a belief and awareness of doctrinal truths or values that are manifested in attitudes and behavior Indonesian Language.

According to Mulyana (2004) as quoted from Reber (1988) said internalization is uniting values in a person, or in the language of Psychology is an adjustment to beliefs, values, attitudes, practices, and standard rules on a person. Meanwhile, according to Kartono (1996) internalization is a setting into the mind or personality, actions, values, standards, ideas or practices of other people to be a part of themselves.

From some of the above explanations, internalization is necessarily a process of instilling something whereas the internalization of socio-cultural values is a process of inculcating the socio-cultural values of the community, wherein the context of this research the Minahasa / North Sulawesi social-cultural values that are trying to be internalized in Civics Education Learning in schools (Pangalila, 2013).

\section{B. Local Wisdom}

Etymologically, local wisdom comes from the words wisdom and local. Local means local, local, while wisdom (wisdom) or wisdom. From the definition above, local wisdom can be interpreted as ideas, values, local culture that are wise, full of wisdom, good value, embedded and followed by community members (Syamsiar, 2010).

In the anthropological discipline, local wisdom is better known as a local genius. Local genius is a term first introduced by Quaritch Wales. In Indonesia, this local genius is discussed at length by anthropologists, including Haryati Soebadio who says that local genius is also a cultural identity, identity/personality of the national culture that causes the nation to absorb and cultivate foreign cultures according to their character and abilities (Rohaedi, 1986). Moendardjito in (Rohaedi, 1986) said that the element of regional culture is potential as a local genius because it has proven its ability to survive until now. Its characteristics are:

1. Able to defend against external culture.

2. Having the ability to accommodate outside cultural elements.

3. Having the ability to integrate outside cultural elements into indigenous culture.

4. Having controlling ability.

5. Able to give direction to cultural development.

On the other hand according to Purba (1999) wisdom or wisdom can be understood as a collective understanding, knowledge and wisdom that influences a decision to resolve or overcome a life problem. Wisdom in this case is an embodiment of a set of understandings and knowledge that undergoes a developmental process by a group of local communities or communities gathered from a long process and experience in interacting in a system and in a bond of mutually beneficial relationships (Marfai, 2012).

From some of the meanings of local wisdom above, it can be said that local wisdom is the basis or benchmark for the government and society in making decisions at the regional level in various fields including education and processing of natural resources. The wisdom of local culture is thus local knowledge that has long existed in the community and has been integrated with the system of beliefs, norms and culture and expressed in the traditions and myths that have been adhered to for a long time and survived the exposure of foreign cultures (Pangalila, 2013).

\section{Local Wisdom of Si Tou Timou Tumou Tou (Humans Live to Humanize Others)}

Si Tou Timou Tитои Tou is a philosophical expression of the Minahasa people especially since Christianity entered the Land of Minahasa, then was intellectually reappointed by Sam Ratulangi. The expression Si Tou Timou Tumou Tou contains the following meanings: (a). Humans are born and live as humans, (b). Humans who live, are living in an adult, responsible and independent, (c). Adult humans, responsible and independent are characterized by "dedication" to "form and give birth" new humans who are mature (through the educational process), responsible and independent later on in the future, for the next new human who has formed that continues the task his service in the context of "organizing" his fellow human beings (Sondak, 2002). The concept of $S i$ Tои Timou Tитои Tоu is a cultural value of the people of North Sulawesi and specifically the Minahasa people who are inherited from generation to generation. In this concept, there are essential values in life that can function as a driver, controlling life, both in maintaining existence and survival and in developing themselves.

\section{The Essence of Civics Education}

According to Sumantri (2008) as quoted from Encyclopedia Americana (1981) states that civics education is: "the promotion of good citizens that can be considered the major all-pervading purpose of education" or can be interpreted as a promotion of good citizenship that can be considered as the main factor that permeates the purpose of education. Furthermore Sumantri (2008) said that: "Several terms have been used to mean "citizenship education" according to the aims of educational system in every country, every period of time or fashion, and every step of national development, or according to the culture and need of a certain country in promoting educational programs. Frequently used term form ancient Greece to the current time are civics, political education, civic education, public affairs education, and teaching democracy, or moral and value education. These terms also have different logical meanings, but share one aim."

Wahab \& Sapriya (2011),

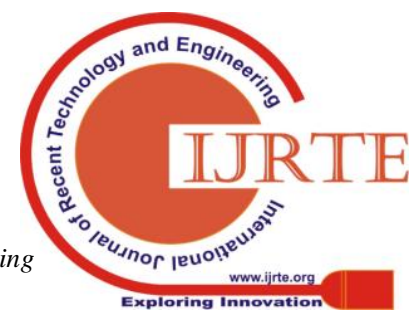


said that: the history of the Indonesian nation shows that traditional formal education has been prepared through one vehicle to prepare citizens who are by national ideals through the social sciences in the curriculum. This effort can be seen from the birth of various names for civic education $(\mathrm{PKn})$ in line with the development and ebb and flow of the journey of Indonesian nation politics.

In line with this according to the Dept. P \& K (1962) as cited by Winataputra \& Budimansyah (200), the development of Civics Education in Indonesia formally began with the emergence of 'civics' courses in the high school curriculum in 1962. This subject contains material about the Indonesian government based on the Constitution. On the other hand according to Somantri (1976) at that time, Civics Education contained learning experiences that were explored and selected from historical, geographical, economic, and political disciplines, presidential speeches, declaration of human rights, and knowledge about the union of nations. The term 'Civics' was formally not found in the 1957 and 1946 curriculum. However, materially in the 1957 Middle and High School Curriculum, there were constitutional subjects and legal procedures in which the concept of citizenship was specifically discussed regarding the legal status of citizens and citizenship requirements (Somantri, 1976). As for the curriculum in 1946, there were general knowledge subjects in which included knowledge about the government. In the curriculum of 1968 and 1969, the terms 'civics' and state civics education were used interchangeably. For example in the elementary school curriculum in 1968 the term civics education was used as the name of the subject matter, which included Indonesian history, Indonesian geography, and 'civics' (which translates to knowledge of citizenship). In the 1968 Middle School curriculum, the term national civics education contained the history of Indonesia and the Constitution including the 1945 Constitution. Whereas in the 1968 high school curriculum state civics subjects contained material especially those relating to the 1945 Constitution. Meanwhile in the SPG curriculum 1969 state civics education subjects especially about Indonesia's history, constitution, social knowledge, and human rights.

In the change of the School Curriculum in 1968 to become the School Curriculum in 1975 which was marked by the merging of some similar subjects into fields of study, producing subject matter related to Pancasila and the 1945 Constitution were separated from subjects related to subjects including history, earth science, and economy. Matters relating to the Pancasila and the 1945 Constitution stand alone as the Field of Study (BS) of Pancasila Moral Education (PMP) while the combined subjects of History, Earth Sciences, and Economics become subjects of Social Sciences (IPS), also known as Social Studies (social studies). The same thing still applies when the 1984 curriculum is applied as a customized curriculum. In the subsequent development of the PMP subject name, due to various changes in all aspects of life and various considerations, the eyes of the subject were adjusted according to the 1994 curriculum. The subject names were changed to Pancasila and Civics Education (PPKn) based primarily on the Republic of Indonesia Law Indonesia No.2 in 1989 concerning the National Education System (Wahab \& Sapriya, 2011). Furthermore, with the enactment of the National Education System Law No. 20 of 2003, the name of the Pancasila and Civics Education lesson (PPKn) was changed again to Civics Education (PKn).

\section{E. Student Tolerance Attitude}

According to Raihani (2011) "Tolerance means patience with differences. In some instances, it connotes the attitude of passiveness towards something disliked, and often it means putting up with or enduring something disliked." In a broad sense, tolerance is more directed towards giving a broad place for diversity and differences that exist in individuals or other groups. Therefore, at the beginning of this discussion, it is necessary to re-emphasize that it is not true that tolerance is defined as the castration of the rights of certain individuals or groups to be adjusted to the conditions or circumstances of other people or groups, or otherwise to redirect the rights of others according to circumstances or certain group conditions. Tolerance actually respects and respects the differences that exist in each or group, but it is bounded and put together in a framework of togetherness for the same interests within. Tolerance is respect, acceptance, and appreciation for diversity that is rich in our world culture, our form of expression and human procedure. It is maintained by knowledge, openness, communication, and freedom of thought, understanding, and trust. Tolerance is harmony in difference (Endang, 2012).

Introducing a diversity of religions, ethnicities, races, languages from an early age must be a priority in the school agenda. This tolerance for diversity must be built early in children. Thus, later, they will live with a correct understanding of diversity and can respect diversity in their interactions with their friends.

\section{METHODOLOGY}

The locations this research was taken place at are in Public and Private High Schools in Tomohon City, North Sulawesi. The population of the samples of this study was all high school students of class XI in Tomohon City, North Sulawesi, which included ten schools. The samples in this study were five high schools in the city of Tomohon, namely: SMA Negeri 1, SMA Negeri 2, SMA Kristen 1, SMA Katolik Karitas, SMA Kosgoro. From those five schools, then was chosen 1 class each from class XI, which resulted in the total numbers of the samples are 120 students.

The approach used by the researcher in obtaining data, achieving the purpose and usefulness of the research is the quantitative approach. The method chosen in this study is the survey method. 


\section{RESULTS AND FINDINGS}

Based on the results of data collection and processing, the researcher obtained a detailed research result for $\mathrm{Si}$ Tou Timou Tumou Tou and Civics Education Learning variables on Student Tolerance Attitudes as follows:

Table Price of Correlation Coefficient between Variables

\begin{tabular}{|l|l|c|c|c|}
\hline \multicolumn{1}{|c|}{ Variable } & $\begin{array}{c}\text { Signific } \\
\text { ation }\end{array}$ & $\begin{array}{c}\text { Correlati } \\
\text { on } \\
\text { Coefficie } \\
\text { nt }\end{array}$ & Notes \\
\hline 2. & $\begin{array}{l}\text { Si Tou Timou Tumou } \\
\text { Touth Civics } \\
\text { Education Learning } \\
\text { (rx1x2) }\end{array}$ & 0.960 & -0.005 & $\begin{array}{c}\text { Very } \\
\text { low }\end{array}$ \\
\hline $\begin{array}{l}\text { Si Tou Timou Tumou } \text { with Student } \\
\text { Tolerance Attitudes } \\
\text { (rx1Y) }\end{array}$ & 0.00 & 0.476 & $\begin{array}{c}\text { Moderat } \\
\text { e }\end{array}$ \\
\hline 3. & $\begin{array}{l}\text { Civics Education } \\
\text { Learning with Student } \\
\text { Tolerance Attitudes } \\
\text { (rx2Y) }\end{array}$ & 0.05 & 0.179 & $\begin{array}{l}\text { Very } \\
\text { low }\end{array}$ \\
\hline
\end{tabular}

After the research data's description and analysis were done, the following is the discussion of some of the research results:

\section{1) The Influence Of Si Tou Timou Tumou Tou} Cultural Value On Civics Education Learning

Based on the results of the study, it was found that the cultural value of Si Tou Timou Tumou Tou did not significantly influence Civics Education learning because the correlation coefficient value was only at -0.05 (very low). Meanwhile, the effect is only $-0,081$ (not significant). The results of this study indicate that so far, the Civics Education Learning carried out in schools, does not accommodate the values contained in the culture of Si Tou Timou Tumou Tou.

Based on the results of interviews with several students, informations were obtained that in the Civics Education Learning process the teacher was less trying to associate learning material with existing cultural values. The teacher is more fixated on the material contained in the curriculum and does not attempt to explore the cultural values of the people of North Sulawesi, such as the cultural value of Si Tou Timou Tитои Tou. It is clear that the results of this study prove that at a practical level, the mission of Citizenship Education ( $\mathrm{PKn})$ which is to educate the life of the Indonesian people through the corridor of "value-based education" is not well implemented. This proves that in the context of Civics Education Learning in schools, the teachers focus more on material and content explicitly written in the curriculum or learning textbooks. The reality found in this study certainly contrasts with the opinion of Koentjaraningrat (2002) who says that "in the enculturation process, an individual learns and adjusts his mind and attitude to customs, systems of norms, and rules that live in his culture." Furthermore, the enculturation process is carried out by parents or people who are considered elder in the community, such as inheriting the values of manners, customs, skills of a tribe/family that are passed on to the next generation. The enculturation process usually takes place formally through education to be conveyed to others who are not familiar, the delivery of information as well as a form of awareness of the existence of a culture and then adopting that culture to serve as its culture.

\section{2) The Influence Of Si Tou Timou Tumou Tou's \\ Cultural Value On Student Tolerance Attitudes}

The results of the study show that the effect of Si Tou Timou Tumou Tou's cultural value variable on the Tolerance Attitude of Students has a correlation coefficient of 0.476 and is in the medium category, while the effect is $2.82 \%$. Based on the results of hypothesis testing, it can be concluded that the cultural value of $\mathrm{Si}$ Tou Timou Tumou Tou has a significant influence on the development of student tolerance. This shows that the higher the student's understanding of human concepts that include them and their friends, the higher the tolerance attitude of the student.

This study also reinforces the opinion of Geertz (1977) who said that culture is: "a historically transmitted pattern of meanings embodied in symbols, a system of inherited conceptions expressed in symbolic forms using which men communicate, perpetuate, and develop their knowledge about and their attitudes toward life." From this definition, Geertz explained that culture is "a historical transmission pattern of meaning that incorporate in symbols, a system of conception that is inherited and presented in the form of symbols the way humans communicate, preserve, and develop their knowledge and attitudes towards life." Based on his definition of culture, Geertz wants to emphasize that culture is an active and constitutive dimension of social life rather than just a guarantee mechanism for social integration. In this cultural value, Si Tou Timou Tumou Tou contains fundamental values in life that can function as a driver, controlling life, both in maintaining existence and survival, as well as for the development of itself. Therefore, the more students have a good understanding of these cultural values, the higher their tolerance for others.

\section{3) The Influence Of Civics Education Learning On} Student Tolerance Attitudes

The results of the research show that the influence of Civics Education Learning variables on Students' Tolerance Attitudes has a correlation coefficient of 0.179 and is in the deficient category, while the effect is $1.35 \%$. Based on the results of hypothesis testing, it can be concluded that Civics Education Learning has a significant influence on the development of students' tolerance attitudes, despite very low. This clearly shows that Civics Education learning concerning preparation, implementation of learning steps, and evaluation must be done better so that the development of students' tolerance can be better.

In this study, the influence of Civics Education learning on the Tolerance Attitude of Students was in a deficient category, because Civics Education learning that was examined in this study was more focused on Civics Education learning that internalized the cultural values of North Sulawesi people. 
Although the effect is small, the results of this study still reinforce the opinion of the Ministry of Education (2003: 7) which states: "Civic Education is a subject that focuses on self-establishment that varies in terms of religion, socio-cultural, language, age and ethnicity to be an intelligent, skilled, and characteristical Indonesian citizen who is mandated by Pancasila and the 1945 Constitution ".

Value-based PKn learning is essentially aimed at developing student citizenship competencies which will later influence the development of student tolerance. Citizenship competence by Branson (1998) is divided into 3, namely: 1) Civic knowledge, related to the content or what should be known by citizens; 2) Civic skills, are relevant intellectual and participatory skills of citizens; and 3) Civic disposition which implies both public and private characters that are important for the maintenance and development of constitutional democracy.

4) The Influence Of Si Tou Timou Tumou Tou's Cultural Value And Civics Education Learning On Student Tolerance Attitudes

The results of this study reinforce the principle of the psychology flow of behaviorism. This theory was developed by behavioristic figures including Edward Thorndike, Jhon Broadus Watson, Clark L. Hull, Edwin Guthrie, and B. F Skinner (Supardan, 2011). The basic principle of the psychology flow of behaviorism says that changes in a person's behavior or attitude are determined by the insights or knowledge they learn. Or in other words, this flow emphasizes the formation of behaviors that appear as learning outcomes (Stimulus-Response). If connected to the results of this study, the development of the Tolerance Attitude of Students is greatly influenced by the increasing student's knowledge or understanding of cultural values that can be obtained at school or in the community. Meanwhile, according to Yusuf \& Nurihsan (2008), factors that influence the development of a person's personality or attitude are largely influenced by two main factors, namely genetics and environmental factors. Regarding the environmental factor, the author divides it again into family, cultural and school environments.

The educational environment includes: family environment, school environment, and community (social) environment. The purpose of education in the family is the establishment of mentality, attitudes, and prominence of positive and constructive behavior, not only in the family environment but in every environment in which the person is located. The role of the School/College, if viewed from a social and spiritual perspective, functions to develop a mental attitude that is closely related to the norms of life on campus and in the community. Thus the type of environment is very decisive and influences the establishment of attitudes, acceptance, behavior, and tolerance of each student towards various pluralities (ethnicity, organization, and religion). This indicates that environmental education cannot be ignored as an important factor in measuring tolerance among students.

According to Mulyana (2004), Ki Hajar Dewantara has long proclaimed the existence of three educational environments called tri-education center. The three environments are school, family and community. In the national education development program, the three of them become an educational cultivated area listed in the National Education System Constitution which is often called a formal, informal, and informal education environment.

In line with the opinion of Ki Hajar Diwantara above and in relation to Civics Education's goal of fostering a citizen into a smart citizen, Civics Education learning in schools must also be carried out comprehensively in various educational environments (schools, communities, and families). The three educational environments play an important role in the success of children's education. The family environment is informal education that runs naturally between parents and children. School environment is a formal education environment that is formed intentionally and institutionalized in which there is a relationship between teacher and student. The community environment is a non-formal education environment whose implementation involves broad community participation (Mulyana, 2004).

According to a research done by Raihani (2011) entitled "A Whole-School Approach: A Proposal for Education for Tolerance in Indonesia" it is found that in the context of developing students' tolerance, their dimensions were not only about explicit curriculum and textbooks, but also about school as a whole. Efforts to research and refine school subject curricula that inculcate tolerance education should be rewarded, but to accommodate the complexity of the value of education, it is important to have a comprehensive understanding of schools. For Raihani (2011), there are six elements of the school that significantly influence the high tolerance of students, namely: School Vision and Policy, Leadership and Management, Curriculum and Teaching, Capacity and Culture, Student Activities, Collaboration with Broad Communities.

\section{CONCLUSION}

\section{A. Conclusion}

Based on the results of descriptive analysis, hypotheses testing and research findings in this study, the general conclusions of this study are: First, the cultural value of Si Tou Timou Tumou Tou, does not positively affect Civics Education learning because in this context cultural values are only a small part of the Civics Education learning material and content in high schools in Tomohon-North Sulawesi. Second, Civics Education Learning has a significant influence on the development of Student Tolerance Attitudes. Civics Education learning that is well prepared and the cultural values that are to be internalized are well identified, well taught and evaluated well, will result in better Attitude of Student Tolerance. Third, the cultural value of Si Tou Timou Tumou Tou and Civics Education Learning together have a positive and significant influence on the development of Student Tolerance Attitudes.

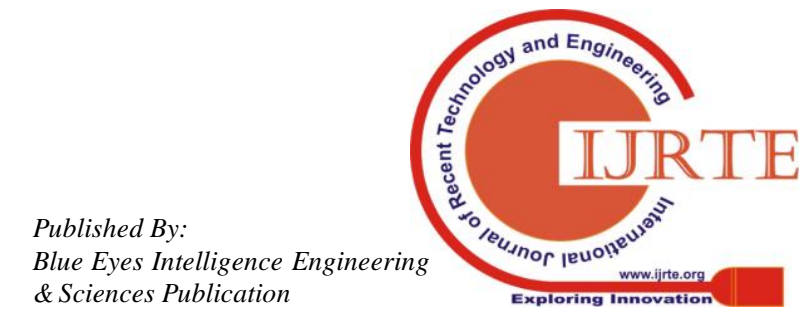




\section{B. Recommendations}

Based on the results of data analysis and conclusions in this research, there are several suggestions relating to the internalization of Si Tou Timou Tumou Tou's local wisdom in Civics Education Learning towards the development of Student Tolerance Attitudes, namely as follows: First, in Civics Education Learning in Indonesia, the position of cultural values as a source of learning must be increased again, because this research proves that cultural values lack or do not contribute to Civics Education Learning. Second, the increase in students' understanding of Si Tou Timou Tumou Tou's cultural values needs to be maintained and improved continuously, because the more this cultural value is maintained and enhanced, the Attitude of Student Tolerance will also stay sustained, and the people of North Sulawesi will live in a harmonious atmosphere. Third, cultural value-based Civics Education learning needs to be better formulated so that the results are more positive towards the development of students' tolerance attitudes.

\section{REFERENCES}

[1] Branson, M. S. (1998). The role of civic education: A forthcoming Education Policy Task Force position paper from the Communitarian Network. Center for Civic Education. Retrieved from http://www.civiced.org/papers/articles_role.html

[2] Endang, B. (2012). Mengembangkan Sikap Toleransi dan Kebersamaan di Kalangan Siswa. Jurnal Visi Ilmu Pendidikan, 1(2), 89-104.

[3] Geertz, C. (1977). The Interpretation of Cultures: Selected Essays. New York: BASIC Books (NY).

[4] Kartono, K. (1996). Pendidikan politik: sebagian dari pendidikan orang dewasa. Mandar Maju.

[5] Kementerian Pendidikan dan Kebudayaan RI. (2010). Desai induk pengembangan karakter bangsa tahun 2010-2025. Jakarta: Kementerian Pendidikan dan Kebudayaan RI.

[6] Koentjaraningrat. (2002). Pengantar Ilmu Antropologi. Jakarta: Rineka Cipta.

[7] Mahfud, C. (2009). Pendidikan Multikultural. Pustaka Pelajar.

[8] Marfai, M. A. (2012). Pengantar etika lingkungan dan Kearifan lokal. Yogyakarta: Gadjah Mada University Press.

[9] Mulyana, R. (2004). Mengartikulasikan pendidikan nilai. Bandung: Alfabeta.

[10] Pangalila, T. (2013). Pengaruh internalisasi nilai budaya Si Tou Timou Tumou Tou, Mapalus dan Torang Samua Basudara Dalam Pembelajaran PKn Terhadap Peningkatan Sikap Toleransi Siswa: Penelitian Survey Terhadap Siswa SMA di Kota Tomohon-Sulawesi Utara. Universitas Pendidikan Indonesia, Bandung.

[11] Pangalila, T., Ngarawula, B., \& Sadhana, K. (2018). Tolerance behavior among society in city of Tomohon, North Sulawesi. International Journal of Humanities and Social Science Research, 4(4), 46-49. https://doi.org/doi.org/10.22271/social

[12] Purba, A. (1999). Emotional Intelligence: Seri Ayah-Bunda. Jakarta: Dian Raya.

[13] Raihani. (2011). A whole-school approach: A proposal for education for tolerance in Indonesia. School Field, 9(1), 23-39.

[14] Rohaedi, A. (1986). Kepribadian Budaya Bangsa. Jakarta: Pustaka Jaya.

[15] Somantri, M. N. (1976). Metode mengajar civics. Erlangga, Jakarta.

[16] Sondak, A. J. (2002). Si Tou Tiimou Tumou Tou (Tou Minahasa): Refleksi atas Nilai-Nilai Manusia. Jakarta: Pustaka Sinar Harapan.

[17] Sumantri, E. (2008). An Outline Citizenship and Moral Education in Major Countries of Southeast Asia. Bandung: Bintang Warliartika. Bandung.

[18] Supardan, D. (2011). Pengantar Ilmu Sosial: Sebuah kajian pendekatan struktural. Jakarta: Bumi Aksara.

[19] Syamsiar, S. (2010). Bentuk-Bentuk Kearifan Lokal Dalam Kehidupan Masyarakat Indonesia Sebagai Sumber Gagasan Berkarya Seni Rupa. Jurnal ISI Surakarta, 2(1). Retrieved from http://jurnal.isi-ska.ac.id/index.php/brikolase/article/view/414

[20] Wahab, A. A., \& Sapriya. (2011). Teori dan landasan pendidikan kewarganegaraan. Bandung: Alfabeta.

[21] Winataputra, U. S., \& Budimansyah, D. (2007). Civic education: Konteks, landasan, bahan ajar, dan kultur kelas. Bandung: Program Studi Pendidikan Kewarganegaraan SPS UPI
[22] Yusuf, S., \& Nurihsan, J. (2008). Teori kepribadian. Bandung: Remaja Rosdakarya. Bandung: Remaja Rosdakarya.

\section{AUTHOR PROFILE}

\section{Arie Supriati}

Currently I am associated with Universitas Negeri Manado and my area of research is Civic Education.

Theodorus Pangalila

I am Theodorus Pangalila currently I am associated with Universitas Negeri Manado and my area of research is Civic Education.

Apeles Lexi Lonto

I am associated with Universitas Negeri Manado and my area of research is Civic Education.

\section{Julien Biringan}

currently I am associated with Universitas Negeri Manado and my area of research is Education. 